\title{
INTRODUCTION TO DETONATION THEORY
}




\section{David H. Sharp and L. M. Simmons, Jr., editors LOS ALAMOS SERIES IN BASIC AND APPLIED SCIENCES}

During its cataclysmic eruptions over a million years ago, the great Jemez volcano deposited enormous quantities of ash, pumice, and other debris. Compacted to form a soft rock, and extending to depths of more than a thousand feet, this is the material of the Pajarito Plateau in north-central New Mexico. The Los Alamos Scientific Laboratory is situated here, at an elevation of 7300 feet, on the eastern edge of the Jemez range. The plateau is deeply cut by numerous canyons which create sheer walls and mesas of striking beauty. The motifs on the jacket and title page are sketches of this terrain, as viewed from the valley of the Rio Grande. 


\section{INTRODUCTION TO DETONATION THEORY}

\section{Wildon Fickett}

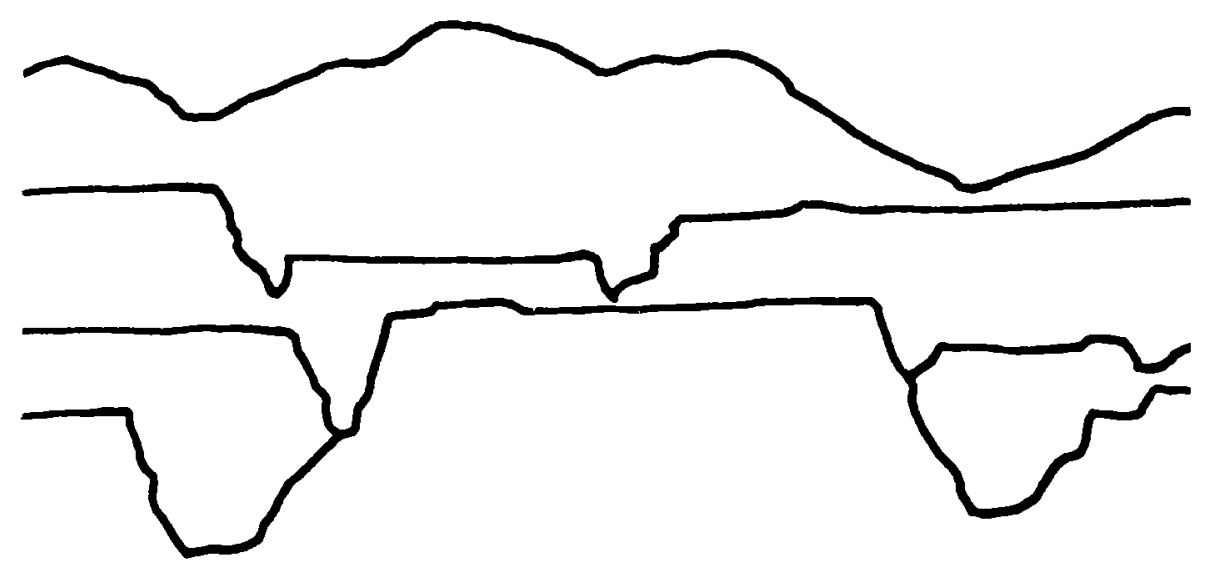

UNIVERSITY OF CALIFORNIA PRESS

Berkeley - Los Angeles • London 
University of California Press

Berkeley and Los Angeles, California

University of California Press, Ltd

London, England

Copyright (C) 1985 by

The Regents of the University of California

ISBN 0-520-05125-4

Library of Congress Catalog Card Number: 85-040105

Printed in the United States of America 
To Ella Mae

Spring rides no horses down the hill, But comes on foot, a goose girl still. And all the loveliest things there be Come simply, so, it seems to me. ...

—Edna St. Vincent Millay 
